\title{
PENGARUH MASSAGE AROMATHERAPHY LAVENDER TERHADAP PERUBAHAN TEKANAN DARAH PADA IBU HAMIL DENGAN PREEKLAMPSIA DI PBM. LILIS SURYAWATI DESA SAMBONG DUKUH KECAMATAN JOMBANG KABUPATEN JOMBANG
}

\section{The Effect Of Lavender Aromatheraphy Massage On Blood Pressure Change In Pregnant Women With Preeklampsia In Bidan Mandiri Practices Lilis Suryawati Sambong Dukuh Village, Jombang.}

\author{
Any Isro'aini \\ Dosen D3 Kebidanan \\ Prodi D3 Kebidanan STIKes ICMe Jombang \\ Jl. Kemuning No. 57 Candi Mulyo, Jombang, Jawa Timur \\ any_isroaini@yahoo.co.id
}

\begin{abstract}
ABSTRAK
Hipertensi pada preeklampsia ditemukan pada ibu hamil dengan usia kehamilan > 20 minggu. Hipertensi didefinisikan dimana tekanan sistolik diatas $140 \mathrm{mmHg}$ dan tekanan diastolic diatas $90 \mathrm{mmHg}$. Penanganan hipertensi pada ibu hamil sampai saat ini masih menggunakan terapi farmakologi atau obat obatan sebesar $100 \%$. Salah satu terapi nonfarmakologi yang dapat menurunkan tekanan darah adalah terapi pijat aromatherapy lavender. Tujuan penelitian ini untuk mengetahui pengaruh pijat aromatherapy lavender terhadap penurunan tekanan darah pada ibu hamil dengan preeklampsia.

Desain penelitian ini menggunakan Quasy Experiment Design dengan rancangan penelitian Control Time Series Design, dimana penelitian ini menggunakan dua kelompok yang terbagi dalam kelompok eksperimen dan kelompok kontrol. Dalam penelitian ini kedua kelompok dilakukan pre-test dan setelah diberikan perlakuan pada kelompok eksperimenakan dilakukan post-test pada kedua kelompok. Sampel penelitian berjumlah 50 responden, dimana 25 responden menjadi kelompok eksperimen dan 25 menjadi kelompok kontrol. Penelitian ini bertempat di PBM. Lilis Suryawati desa Sambong Dukuh Kecamatan Jombang Kabupaten Jombang. Penelitian ini dilakukan pada bulan Februari sampai dengan bulan April 2018.

Hasil penelitian menunjukkan adanya perbedaan signifikan antara tekanan darah kelompok eksperimen yang mendapat perlakuan dan kelompok kontrol yang tidak mendapat perlakuan. Tekanan darah sistolik kedua kelompok nilai $p$-value 0,003 dan nilai $\mathrm{Z}-4,007$. Sedangkan tekanan darah diastolic pada kedua kelompok $p$-value 0,000 dan nilai Z -5,559.

Diharapkan bagi profesi kebidanan dapat memberikan informasi tentang pentingnya dilakukan pijat aromatherapy lavender untuk menurunkan tekanan darah pada ibu hamil dengan preeklampsia, sehingga bisa meminimalkan terjadinya komplikasi pada ibu hamil dengan preeklampsia.
\end{abstract}

Kata Kunci: Pijat, Aromatherapy lavender, Ibu hamil, Preeklampsia. 


\begin{abstract}
Hypertension in preeclampsia is found in pregnant women with gestational age $>20$ weeks. Hypertension is defined where systolic pressure above $140 \mathrm{mmHg}$ and diastolic pressure above $90 \mathrm{mmHg}$. Handling hypertension in pregnant women up to now is still using pharmacological therapy or drugs by $100 \%$. One nonpharmacological therapy that can lower blood pressure is aromatherapy lavender massage therapy. The purpose of this study was to determine the effect of lavender aromatherapy massage on blood pressure reduction in pregnant women with preeclampsia.

The design of this study used the Quasy Experiment Design with the Control Time Series Design research design, where the study used two groups divided into experimental groups and control groups. In this study both groups were pre-tested and after being given treatment in the experimental group a post-test was carried out in both groups. The research sample amounted to 50 respondents, of which 25 respondents became the experimental group and 25 became the control group. This research took place at PBM. Lilis Suryawati, Sambong village, Dukuh, Jombang District, Jombang Regency. This research was conducted from February to April 201.

The results showed a significant difference between the blood pressure of the experimental group who were treated and the control group that was not treated. The systolic blood pressure of both groups pvalue 0.003 and the value of $Z-4.007$. While diastolic blood pressure in both groups p-value 0,000 and $Z$ value $-5,559$.

It is expected that the midwifery profession can provide information about the importance of aromatherapy lavender massage to reduce blood pressure in pregnant women with preeclampsia, so that it can minimize the occurrence of complications in pregnant women with preeclampsia.
\end{abstract}

Keywords: Massage, Aromatherapy lavender, Pregnant women, Preeclampsia.

\section{PENDAHULUAN}

Preeklampsia menempati urutan kedua penyebab kematian ibu setelah perdarahan. Preeklampsia merupakan kondisi dimana tekanan darah dan protein dalam urine naik setelah 20 minggu kehamilan. Mengontrol tekanan darah tinggi merupakan bagian penting dalam pengobatan preeklampsia. Salah satu indikator untuk menilai tingkat pelayanan kesehatan di suatu negara terutama untuk ibu hamil, melahirkan dan nifas, adalah berdasarkan angka kematian maternal. Berdasarkan Overview of Maternal Health in ASEAN Countries pada tahun 2011 oleh WHO, dilaporkan bahwa Indonesia menduduki peringkat tiga tertinggi di kawasan ASEAN, untuk jumlah kematian maternal setelah negara Laos dan Cambodja.

Angka Kematian Ibu (AKI) di Indonesia berdasarkan SDKI tahun 2007 dan 2012 masih tinggi yaitu 228 dan 359 per 100.000 kelahiran. Angka ini masih jauh dari target capaian MDGs 2015 yaitu 102 per 100.000 kelahiran hidup. Kasus kematian ibu di Indonesia di tahun 2013 berdasarkan data pusdatin disebabkan oleh perdarahan (30,3\%), hipertensi (27,1\%), infeksi (7,3\%), penyebab lainnya $(40,8 \%)$. Berdasarkan data dari profil kesehatan tahun 2012 dan 2013 Propinsi Jawa Timur, Angka Kematian Ibu sebesar 97,43 per 100.000 kelahiran hidup dan 97,13 per 100.000 kelahiran hidup. Angka ini menurun di tahun 2014 mencapai 93,52 per 100.000 kelahiran. Data tersebut menunjukkan bahwa Propinsi Jawa Timur telah mencapai target MDGs 2015. Preeklampsia dan eklampsia masih merupakan faktor dominan penyebab kematian ibu di Jawa Timur pada tahun 2017, yaitu 38\% (Dinas Kesehatan Propinsi Jatim, 2017).

Profil Dinas Kesehatan

Kabupaten Jombang melaporkan jumlah kematian ibu sampai dengan bulan desember 2017 terdapat 28 kematian/KH. Hal ini mengalami peningkatan dari tahun 2016 dimana jumlah kematian 17 kematian/KH. 28 kematian yang terjadi pada tahun 2017 terdiri dari 5 kasus karena Pre eklampsia, 4 kasus HPP (Haemorrhagie Post-Partum), 3 kasus eklampsia, 2 kasus emboli ketuban, 1 
kasus APB (Ante Partum Blooding) dan 13 kasus kematian karena penyebab lain seperti riwayat penyakit yang menyertai. Masih banyaknya kasus kematian ibu karena Pre eklampsia/eklampsia di Kabupaten Jombang, perlu dilakukan upaya nyata pada sistem pemeriksaan kehamilan dalam melakukan deteksi dini dan intervensi efektif pada kasus pre eklampsia/eklampsia.

Salah satu tanda dan gejala dari preeklampsia adalah terjadinya hipertensi. Hipertensi pada preeklampsia ditemukan pada ibu hamil dengan usia kehamilan > 20 minggu. Hipertensi dapat didefinisikan dimana tekanan sistolik diatas $140 \mathrm{mmHg}$ dan tekanan diastolic diatas $90 \mathrm{mmHg}$. Penanganan hipertensi pada ibu hamil sampai saat ini masih menggunakan terapi farmakologi atau obat -obatan sebesar 100\% (Sarwono, 2015). Salah satu terapi nonfarmakologi yang dapat menurunkan tekanan darah adalah terapi pijat aromatherapy lavender.

Pijat aromatherapy lavender merupakan pilihan terapilain selain relaksasi nafas dalam, dimana terapi ini menggunakan minyak esensial dengan aroma lavender yang mampu menembus kulit danterserap ke dalam tubuh, sehingga memberikan pengaruh penyembuhan dan menguntungkan pada berbagai jaringan dan organ internal (Koensoermardiyah, 2013).

Secara fisiologis, pijatan dengan aromatherapy lavender merangsang dan mengatur tubuh, memperbaiki aliran darah dan kelenjer getah bening, sehingga oksigen, zat makanan, dan sisa makanan dibawa secara efektif dari jaringan tubuh dan plasenta. Dengan pijat aromatherapy lavender bisa menurunkan emosi, merelaksasi dan menenangkan saraf, serta membantu menurunkan tekanan darah.

Pada ibu hamil yang mengalami hipertensi, pemberian terapi pijat aromatherapy lavender membantu ibu merasa lebih rileks dan nyaman. Sebuah penelitian menyebutkan, ibu hamil yang melakukan teknik relaksasi nafas dalam dan dilakukan pijat 20 menit setiap jam setiap satu minggu akan lebih meminimalkan resiko terjadinya hipertensi. Hal itu terjadi karena pijat merangsang tubuh melepaskan senyawa endorphin yang dapat menciptakan perasaan nyaman dan enak.

\section{METODE PENELITIAN}

Desain penelitian ini menggunakan Quasy Experiment Design dengan rancangan penelitian Control Time Series Design, dimana dalam penelitian ini menggunakan dua kelompok yang terbagi dalam kelompok eksperimen dan kelompok control. Penelitian ini bertempat di BPM Lilis Suryawati desa Sambongdukuh kecamatan Jombang Kabupaten Jombang, dilakukan pada bulan Februari sampai dengan bulan April 2018. Sampel penelitian ini berjumlah 50 responden, dimana 25 responden menjadi kelompok eksperimen dan 25 menjadi kelompok control. Dalam penelitian ini kedua kelompok dilakukan pre-test dan setelah diberikan perlakuan pada kelompok eksperimenakan dilakukan post-test pada kedua kelompok (Notoatmodjo, 2010).

\section{HASIL PENELITIAN}

A. Data Umum

Tabel 1. Distribusi Frekwensi Data Umum Responden.

\begin{tabular}{|c|c|c|c|c|}
\hline \multirow{3}{*}{ Distribusi } & \multicolumn{4}{|c|}{ Jumlah } \\
\hline & \multicolumn{2}{|c|}{$\begin{array}{c}\text { Kelompok } \\
\text { Eksperime } \\
n\end{array}$} & \multicolumn{2}{|c|}{$\begin{array}{l}\text { Kelompo } \\
\text { k Kontrol }\end{array}$} \\
\hline & $\mathrm{f}$ & $\%$ & $\mathrm{f}$ & $\%$ \\
\hline \multicolumn{5}{|l|}{ Usia } \\
\hline $18-35$ th & 20 & 80 & 10 & 40 \\
\hline$>35$ th & 5 & 20 & 15 & 15 \\
\hline \multicolumn{5}{|l|}{ Persalinan } \\
\hline Primigravida & 9 & 36 & 10 & 40 \\
\hline Multigravida & 16 & 64 & 15 & 60 \\
\hline \multicolumn{5}{|l|}{ Pekerjaan } \\
\hline IRT & 7 & 28 & 9 & 36 \\
\hline Buruh Pabrik & 8 & 32 & 5 & 20 \\
\hline Guru & 10 & 40 & 11 & 46 \\
\hline Pendidikan & & & & \\
\hline
\end{tabular}




\begin{tabular}{ccccc}
\hline SMA & 14 & 56 & 13 & 52 \\
\hline PT & 11 & 46 & 12 & 48
\end{tabular}

Sumber : Data Primer, 2018.

Dari tabel 1 diperoleh hasil bahwa: $80 \%$ responden pada kelompok eksperimen berusia 18-35 tahun, dan 40\% responden pada kelompok control berusia $>35$ tahun. Sedangkan berdasarkan persalinan, 64\% responden pada kelompok eksperimen adalah multigravida, dan $64 \%$ pada kelompok control adalah primigravida. Berdasarkan pekerjaan sebagian besar reponden pekerjaannya adalah guru, yaitu 10\% responden pada kelompok eksperimen, dan $46 \%$ responden pada kelompok kontrol. Berdasarkan pendidikan sebagian besar responden pendidikannya adalah perguruan tinggi,yaitu $46 \%$ reponden pada kelompok eksperimen dan $48 \%$ responden pada kelompok kontrol.

B. Data Khusus

1. Tekanan Darah Sistolik

Tabel 2. Perbandingan Tekanan Darah Sistolik Pada Ibu Hamil Dengan Preeklampsia Pada Kelompok Eksperimen Dan Kelompok Kontrol.

\begin{tabular}{ccccc}
\hline Kel & $\begin{array}{c}\text { Tekanan } \\
\text { darah } \\
\text { sistolik }\end{array}$ & Mean & $\begin{array}{c}\text { p- } \\
\text { value }\end{array}$ & $\mathrm{Z}$ \\
\cline { 1 - 3 } Eks & Sebelum & 155,20 & & \\
\cline { 2 - 3 } & Setelah & 150,04 & 0,000 & $\begin{array}{c}- \\
5,679\end{array}$ \\
\hline \multirow{2}{*}{ Kntrl } & Sebelum & 155,04 & & \\
\cline { 2 - 3 } & Setelah & 155,29 & 0,457 & -856 \\
\hline
\end{tabular}

Sumber : Data Primer, 2018.

Berdasarkan tabel 2 pada kelompok eksperimen nilai Z -5,679 dan p-value 0,000 terdapat penurunan rata-rata tekanan darah sistolik pre-testdan post-test, karena nilai $\mathrm{p}$ value $0,000 \leq 0,05$. Sedangkan kelompok kontrol nilai Z -856 dan p-value 0,457 tidak terdapat penurunan tekanan darah sistolik pre-test dan post-test, karena nilai p-value $0,457>0,05$.

\section{Tekanan Darah Diastolik}

Tabel 3. Perbandingan Tekanan Darah Diastolik Pada Ibu Hamil Dengan Preeklampsia Pada Kelompok Eksperimen Dan Kelompok Kontrol.

\begin{tabular}{ccccc}
\hline Kel & $\begin{array}{c}\text { Tekanan } \\
\text { darah } \\
\text { diastolik }\end{array}$ & Mean & $\begin{array}{c}\mathrm{p}- \\
\text { value }\end{array}$ & $\mathrm{Z}$ \\
& & & \\
\hline
\end{tabular}

\begin{tabular}{|c|c|c|c|c|}
\hline \multirow[b]{2}{*}{ Eks } & Sebelum & 92,20 & \multirow[b]{2}{*}{0,000} & \multirow[b]{2}{*}{$-5,637$} \\
\hline & Setelah & 93,89 & & \\
\hline & Sebelum & 96,09 & & \\
\hline Kntrl & Setelah & 89,06 & 0,000 & $-5,135$ \\
\hline
\end{tabular}

Sumber : Data Primer, 2018.

Berdasarkan tabel 3 pada kelompok eksperimen nilai $\mathrm{Z}-5,637$ dan $\mathrm{p}$-value 0,000 terdapat penurunan rata-rata tekanan darah diastolikpre-testdan post-test, karena nilai $\mathrm{p}$ value $0,000 \leq 0,05$. Sedangkan kelompok kontrol nilai $\mathrm{Z}-5,135$ dan $\mathrm{p}$-value 0,000 terdapat penurunan tekanan darah diastolik pre-test dan post-test.

3. Perbandingan tekanan darah pada ibu hamil dengan preeklampsia pada kelompok eksperimen dan kelompok control pada saat post-test.

Tabel 4. Perbandingan Tekanan Darah Pada Ibu Hamil Dengan Preeklampsia Pada Kelompok Eksperimen Dan Kelompok Control Pada Saat Post-Test.

\begin{tabular}{|c|c|c|c|}
\hline $\begin{array}{c}\text { Tekanan } \\
\text { Darah }\end{array}$ & Mean & P-Value & $\mathrm{Z}$ \\
\hline $\begin{array}{l}\text { Sistolik } \\
\text { Eksp }\end{array}$ & 150,04 & \multirow[t]{2}{*}{0,003} & \multirow[t]{2}{*}{$-4,007$} \\
\hline $\begin{array}{l}\text { Sistolik } \\
\text { Kntrl }\end{array}$ & 155,29 & & \\
\hline $\begin{array}{c}\text { Diastolik } \\
\text { Eksp }\end{array}$ & 93,89 & \multirow[t]{2}{*}{0,000} & \multirow[t]{2}{*}{$-5,559$} \\
\hline $\begin{array}{c}\text { Diastolik } \\
\text { Kntrl }\end{array}$ & 89,06 & & \\
\hline
\end{tabular}

Sumber : Data Primer, 2018.

Berdasarkan tabel 4 pada tekanan darah sistolik kedua kelompok nilai $p$-value 0,003 dan nilai $Z-4,007$. Sedangkan tekanan darah diastolic pada kedua kelompok $p$-value 0,000 dan nilai $Z$-5,559. Maka terdapat adanya perbedaan signifikan antara tekanan darah kelompok eksperimen yang mendapat perlakuan dan kelompok kontrol yang tidak mendapat perlakuan karena nilai $p$-value $\leq$ 0,05 .

\section{PEMBAHASAN}

A. Data Umum

1. Karakteristik responden berdasarkan usia menunjukkan bahwa rata-rata usia responden pada kelompok eksperimen 18-35 tahun dan pada kelompok kontrol usia $\geq 35$ tahun. Usia merupakan salah satu faktor yang menentukan status kesehatan ibu hamil. Akan tetapi pada kasus preeklampsia usia ibu tidak menjadi 
salah satu faktor resiko kemunculan preeklampsia, melainkan ada faktor lain seperti lingkungan, riwayat penyakit, paritas, gangguan metabolisme dan social ekonomi. Banyaknya kejadian preeklampsia pada usia sehat dikarenakan proses kehamilan dan persalinan paling banyak terjadi di usia 18-35 tahun.

2. Karakteristik responden berdasarkan kehamilan menunjukkan bahwa sebagian besar responden pada kelompok eksperimen dan kontrol dengan kehamilan multigravida. Cunningham (2014), menyebutkan bahwa faktor resiko preeklampsia adalah nullipara, lingkungan, kondisi sosial ekonomi, seasonal influences, obesitas, kehamilan gemelli, usia ibu, gangguan metabolism dan adanya riwayat keluarga dengan preeklampsia atau riwayat preeklampsia sebelumnya. Penelitian hindun (2015) menyebutkan bahwa primigravida memiliki peluang lebih besar 2,875 kali terkena preeklampsia dibandingkan dengan yang bukan primigravida.

3. Pekerjaan

Karakteristik responden berdasarkan pekerjaan menunjukkan bahwa baik pada kelompok eksperimen maupun kelompok kontrol hampir separuhnya responden bekerja sebagai guru. Cunningham (2014), menyebutkan bahwa faktor resiko preeklampsia adalah nullipara, lingkungan, kondisi sosial ekonomi, seasonal influences, obesitas, kehamilan gemelli, usia ibu, gangguan metabolisme dan adanya riwayat keluarga dengan preeklampsia atau riwayat preeklampsia sebelumnya. Dalam faktor sosial ekonomi, salah satu faktor yang menunjang adalah pekerjaan, dimana hampir separuhnya responden bekerja sebagai guru. Guru merupakan aktivitas yang menuntut untuk terus berfikir, dimana pekerjaan seorang guru bisa menjadi penyebab seseorang selalu diabwah tekanan untuk bisa menyelesaikan tugas dan tanggung jawabnya sebagai seorang guru dengan baik. Kondisi selalu dibawah tekanan itulah yang menjadi faktor penyebab gangguan psikologis yang berdampak pada kehamilan ibu. Padila (2014), menyebutkan ibu dengan pendidikan tinggi dan yang bekerja di sector formal mempunyai akses yang lebih baik terhadap informasi tentang kesehatan, lebih aktif menentukan sikap dan lebih mandiri mengambil tindakan perawatan.

4. Pendidikan

Karakteristik responden berdasarkan pendidikan sebagian besar responden baik kelompok kontrol maupun kelompok eksperimen berpendidikan SMA. Tingkat pendidikan seseorang mempengaruhi bagaimana seseorang mengambil keputusan atas masalah kesehatan yang dialaminya. Semakin rendah pendidikan ibu maka akan semakin sedikit keinginan ibu untuk memanfaatkan pelayanan kesehatan. Padila (2014), menyebutkan ibu dengan pendidikan tinggi dan yang bekerja di sector formal mempunyai akses yang lebih baik terhadap informasi tentang kesehatan, lebih aktif menentukan sikap dan lebih mandiri mengambil tindakan perawatan.

B. Data khusus

1. Berdasarkan tabel 2 diatas menunjukkan tekanan darah sistolik sesudah dilakukan pijat aromatherapy lavender didapatka hasil nilai Z -5,679 dan p-value 0,000 , hal ini menunjukkan adanya perubahan terhadap penurunan tekanan darah sistolik setelah diberikan pijat aromatherapy lavender. Sedangkan kelompok kontrol nilai Z -856 dan pvalue 0,457 tidak terdapat penurunan tekanan darah sistolik pre-test dan post-test, karena nilai p-value 0,457 > 0,05. Menurut Batbual (2010) mengungkapakan bahwa pengaruh stimulasi pijat aromatherapy lavender mempunyai efekyaitu melebarkan pembuluh darah dan memperbaiki peredaran darah didalam jaringan tersebut. Hal ini menyebabkan penyaluran zat asam dan bahan makanan ke sel-sel diperbesar dan pembuangan dari zat- zat yang tidak terpakai akan diperbaiki, sehingga menimbulkan pertukaran zat yang 
lebih baik. Stimulus pada pemijatan dengan aromatherapy lavender mengakibatkan aktifitas sel yang meningkat dan mengurangi rasa sakit. Penekanan menyebabkan perangsangan serabut $\mathrm{A}$ delta dan $\mathrm{C}$ yang melepaskan substansi $\mathrm{P}$ untuk mentransmisi impuls melalui mekanisme gerbang. Sinyal nyeri ini biasanya diblok dengan stimulasi serabut A beta. Serabut saraf A beta adalah serat saraf bermielin yang besar sehingga mengantarkan impuls ke system saraf pusat jauh lebih cepat daripada serabut A delta atau serabut C. serabut ini berespon terhadap penekanan pada otot, pergerakan dan stimulasi listrik.

2. Berdasarkan tabel 3 pada kelompok eksperimen nilai $\mathrm{Z}-5,637$ dan p-value 0,000 terdapat penurunan rata-rata tekanan darah diastolik pre-testdan post-test, karena nilai $\mathrm{p}$-value $0,000 \leq$ 0,05 . Sedangkan kelompok kontrol nilai Z $\quad-5,135$ dan p-value 0,000 terdapat penurunan tekanan darah diastolik pre-test dan post-test. Hayens (2006) dalam Sudiarto (2010) tekanan darah diastolik terkait dengan sirkulasi koroner, jika arteri koroner dalam kondisi sehat maka seseorang tidak akan mengalami kenaikan tekanan diastolik. Martha (2012) menyebutkan seseorang yang berada dalam lingkungan atau kondisi stressor yang tinggi sangat memungkinkan terjadi peningkatan tekanan darah. Pada responden dengan kelompok kontrol setelah dievaluasi selama 24 jam, tidak mengalami peningkatan tekanan yang signifikan. Hal ini menunjukkan juga bahwa sebagian besar ibu dengan kehamilan multigravida. Ibu yang sudah mempunyai pengalaman mengenai kehamilan sebelumnya bisa dengan baik menjalani semua perubahan kehamilan baik secara psikis dan fisik.

3. Berdasarkan tabel 4 pada tekanan darah sistolik kedua kelompok nilai $p$ value 0,003 dan nilai $\mathrm{Z}-4,007$. Sedangkan tekanan darah diastolic pada kedua kelompok p-value 0,000 dan nilai $\mathrm{Z}-5,559$. Maka terdapat adanya perbedaan signifikan antara tekanan darah kelompok eksperimen yang mendapat perlakuan dan kelompok kontrol yang tidak mendapat perlakuan karena nilai $p$-value $\leq 0,05$. Pijat aromatherapy lavender pada ibu hamil memberikan pengaruh yang positif terhadap penurunan tekanan darah ibu hamil dengan preeklampsia. Pijat aromatherapy lavender merupakan metode stimulasi pijat yang mempunyai dampak untuk melebarkan pembuluh darah dan memperbaiki peredaran darah didalam jaringan tersebut, sehingga mempermudah proses distribusi oksigen dan zat sari makanan ke dalam sesmua sistem tubuh. Stimulus pada pemijatan dengan aromatherapy lavender mengakibatkan peningkatan aktifitas sel sehingga akan memperlancar proses pertukaran oksigen di dalam tubuh. Pijat aromatherapy lavender memberikan efek penurunan tekanan darah melalui tahapan relaksasi, penurunan aktifitas kardiovaskular, peningkatan vasodilatasi, peningkatan VEGf, menurunkan SFlt-1 pada plasma dan menurunkan tekanan darah. Efek penurunan tekanan darah ini sejalan dengan penelitian Ratna (2015) yang menjelaskan bahwa pijat aromatherapy lavender mampu menurunkan tekanan darah dengan mean rank penurunan sistole 21,00 dan diastole 25,5. Peneliti lain membuktikan bahwa pijat lembut dan hipnoterapi menurunkan tekanan darah dengan nilai penurunan sistolik 16,72 $\mathrm{mmHg}$ dan diastolic $6.82 \mathrm{mmHg}$. Pada pemijatan aromatherapy lavender peneliti memposisikan ibu hamil dengan berbaring miring kiri, perut diganjal bantal kecil dan antar kaki diganjal bantal. Posisi ini memberikan efek maksimal pada penurunan tekanan darah. Hal ini sesuai dengan penjelasan bahwa pada posisi berbaring tekanan darah seseorang akan lebih rendah, dengan tidur miring ke kiri memberikan keuntungan untuk ibu dan bayi akan mendapatkan aliran darah dan nutrisi maksimal ke plasenta karena vena besar dibelakang sebelah kanan spina mengembalikan aliran darah tubuh bagian bawah ke jantung. 


\section{KESIMPULAN}

Penelitian yang dilakukan di di PBM.

Lilis suryawati desa sambong dukuh

Kecamatan jombang kabupaten Jombang dapat disimpulkan sebagai berikut:

1. Sebagian besar responden berusia 1835 tahun

2. Sebagian besar responden kehamilan multigravida

3. Hampir separuh responden bekerja sebagai guru.

4. Sebagian besar responden berpendidikan SMA

5. Terjadi penurunan tekanan darah sistolik pada kelompok eksperimen dan tidak ada penurunan tekanan darah sistolik yang signifikan pada kelompok kontrol.

6. Terjadi penuruna tekanan darah diastolik pada kelompok eksperimen dan kelompok kontrol.

7. Terdapat adanya perbedaan penurunan signifikan antara tekanan darah kelompok eksperimen yang mendapat perlakuan dan kelompok kontrol yang tidak mendapat perlakuan karena nilai $p$-value $\leq 0,05$

\section{KEPUSTAKAAN}

Agusta,A, 2000, Aromaterapi Cara Sehat Dan Wewangian Alami, Penebar Swadaya, Jakarta.

Dinas Kesehatan Kabupaten Jombang. Profil Kabupaten Jombang 2017. Jombang: Dinkes Jombang; 2017.

Dinas Kesehatan Kabupaten Jombang. Profil Kabupaten Jombang 2012. Jombang: Dinkes Jombang; 2013.

Dinas Kesehatan Kabupaten Jombang. Profil Kabupaten Jombang 2013. Jombang: Dinkes Jombang; 2014.

Ditjen Bina Upaya Kesehatan Kementrian Kesehatan RI. Buku Pemantauan Kesehatan Pribadi Lanjut Usia. Jakarta: Kemenkes RI; 2013.
Dainty Maternity, Inhalasi Aromaterapi Dan Morning Sickness, Jakarta; 2017.

Konsoemardiyah, Menurunkan Tingkat Kecemasan Dengan Aromaterapi, Jakarta: 2013

Maya.P, Aromaterapi Bukan Sekedar Wewangian, www. mailarchie.com/mayapadaprana@yahoogrou ps diakses pada 20 Desember 2016.

Notoatmodjo, Metodologi Penelitian Kesehatan, Jakarta: 2010.

Pemprov Jatim. Pemprov Jatim Prioritaskan Lansia. $\quad$ available http://www.jatimprov.go.id/site Acces on 16 of May 2014.

Sri Wahyuni, Pemberian Aromaterapi Untuk Menurunkan Kecemasan Ibu Hamil, Jakarta; 2017.

Subarsono, A. Analisis Kebijakan Publik, Konsep, Aplikasi dan Teori. Yogjakarta: Pustaka Yelajar; 2008.

Winarto Budi. Kebijakan Public Teori Dan Proses. Edisi Revisi. Yogjakarta : Media Pressindo; 200 